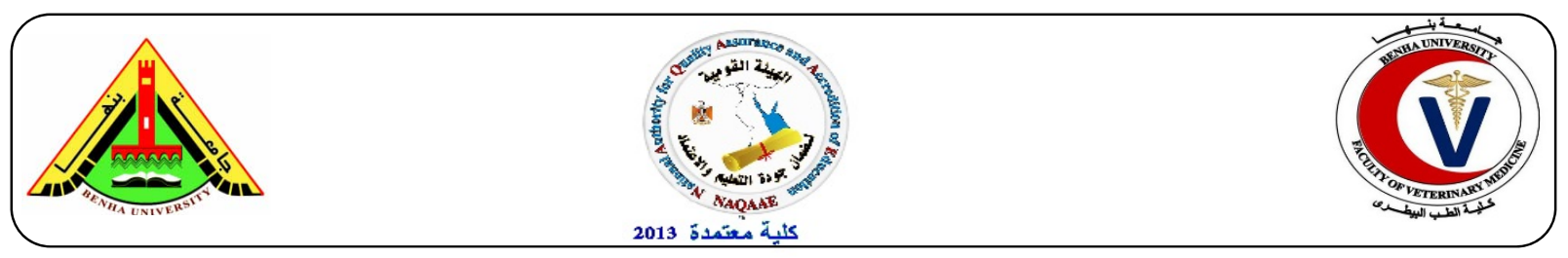

\title{
Effect of level of biosecurity measures on prevalence of some pathogenic micro- organisms in poultry farm
}

\author{
Abdelal, S.A. ${ }^{1}$; Tulip, A. Abdulghaffar ${ }^{1}$; Halla E.K. El Bahgy ${ }^{1}$; Metawea, Y.F ${ }^{1}$ and Kamel, M.H. ${ }^{2}$ \\ ${ }^{1}$ Department of Animal Hygiene Behavior and Management, Faculty of Veterinary Medicine, Benha University. ${ }^{2}$ \\ Officer of the armed forces
}

\begin{abstract}
A B S T R A C T
The present study was performed to evaluate the efficiency of disinfection process applied in poultry farms and determination the major input of infection into poultry farms. A total of 140 samples and swabs were collected from farm A and B with an average of 70 samples from each farm. These samples were collected from floor, walls, drinker, feeder, air, windows, fans, boats, car rubber, cloaca, litter, water, feed and hands samples (5 of each) from two broiler farms before and after disinfection. The results showed that Salmonella Kentuckey, Salmonella Typhymurium, Salmonella Enteritidis and Salmonella Virchow were higher in different samples taken from farm (A) than in different samples taken from farm (B). Actually, E. coli serotype O1 was detected in drinker, boots, cloaca, litter (20\% of each) \& car rubber $(40 \%)$ of farm (A) and only from car rubber (20\%) of farm (B). Moreover, E. coli serotype O2 was isolated from fan, feeder, feed ( $20 \%$ of each) \& boots (40\%) of farm (B). However, E. coli serotype O78 was detected in floor, feeder, cloaca, water (20\% of each) \& feeder \& litter ( $40 \%$ of each) of farm (A) and feeder, cloaca (20\% of each) \& litter (40\%) of farm (B). In concern to S. aureus, the isolation percentages from wall, fan, cloaca, litter (20\% of each), floor, drinker, boots, air (40\% of each), car rubber $(60 \%)$ \& worker hands $(80 \%)$ of farm (A) and only from drinker \& car rubber $(20 \%$ of each) of farm (B). While, C. jejuni was recovered floor, wall, fan, feeder, boots, water (20\% of each), drinker, cloaca ( $40 \%$ of each) \& litter (60\%) of farm (A) and only from cloaca and litter (20\% of each) of farm (B).
\end{abstract}

Key words: Disinfectants, S. Typhimurium, E. coli, S. aureus, Broiler farm.

(http://www.bvmj.bu.edu.eg)

(BVMJ-31(1): 147-153, 2016)

\section{INTRODUCTION}

Biosecurity is an integral part of any successful poultry production system which refers to those measures taken to prevent or control the introduction and spread of infectious agents to the flock. Failure in biosecurity measures resulting in clinical or sub-clinical disease, which significantly reduce the productivity, profitability and long term financial viability of the poultry operation (Sharma, 2010).

In other words, biosecurity means security against biological agents which include bacteria, viruses, protozoa, fungi, parasites, and any other agents capable of introducing an infectious disease into poultry flocks. If agents do enter, the producer will use management practices that will keep their effect to the very minimum (Halifa, 2008).

The major components of biosecurity include isolation, traffic Control and sanitation. Accurately, isolation refers to keep your birds away from other animals as well as application of all-in/all-out management styles which allow simultaneous depopulation between flocks and allow time for periodic clean-up and disinfection to break the cycle of disease. Also, traffic control should be applied into and within the farm. Finally, sanitation addresses the disinfection of materials, people and equipments entering the farm as well as the cleanliness of the personnel on the farm (Jeffrey, 1997).

An additional element to prevent introduction and spread of disease is the use of disinfectants which act on microorganisms at several target sites resulting in membrane disruption, metabolic inhibition and lyses of the cell (Dvorak, 2005; Smith and June, 1999, and Ahmad, 1990)

\section{MATERIALS AND METHODS}

\subsection{Collection of samples}

The present work was done in two broiler farms located at Qaluobia and Sharqia Governorates, to 
evaluate the efficiency of disinfection process as well as to determine the major input of infection into poultry farm.

\subsection{Farms}

\subsubsection{Farm (A)}

The farm contains 3 pens, (50x $10 \times 3$ meter) used for stocking 5000 birds, with east-west direction to the long axis and it located at Tokh province, Qaluobia Governorate. The system used was deep litter-open system. Feeding was carried out according to instructions of the breeding company that supplied the birds, water source was tap water (surface water), downtime was 10 days, and disinfection of the farm was carried out by dry cleaning, followed moist cleaning and finally spraying with commercial phenol at conc. 5\%. The farm contains neither fence nor footbath. Disposal of dead birds was carried out by burring without quick lime at south site of the farm. They was vulnerable to multiple sources of infection such as others poultry and animal farms, hatchers, feed mills and slaughter house as well as human dwelling.

\subsubsection{Farm (B)}

The farm contains 3 pens, $(120 \times 12 \times 3$ meter $)$ used for stocking 28000 birds, with east-west directions to the long axis and it located at Belbeas city, Sharqia Governorate. The system used was deep litter-closed system. Feeding, watering, heating and cooling were carried out automatically through control unit located at service room. Feeding was carried out according to instructions of breeding company that supplied the bird, The source of water was ground water treated by biocide 2000, down time was 15 days, disinfection of the farm carried out by dry, followed by moist cleaning by biosafe $3 \%$ then by spraying $0.5 \%$ of Virocide and finally rinsed with clean water. The farm was surrounded by fence, and supplied by footbath, wheel bath, shower at entrance, alarm system, as well as hygienic burial site for disposal of dead birds. The farm was located in an isolated place away from others poultry and animal farms.

\subsection{Sampling}

\subsubsection{Samples collected before and after disinfection}

A total no of 140 samples and swabs were collected from farm (A) and (B) with an average of 70 samples from each farm. The samples were collected from floor, walls, drinker, feeder, air, windows, fans, boats, car rubber, cloaca, litter, water, feed and hands samples (5 of each) from two broiler farms before and after disinfection. The procedures were carried out according to (Williams, 1975) and (Ahmad, 1990).

\subsection{Preparation of samples}

All collected samples were thoroughly mixed with sterile saline. The prepared samples were subjected to the following examination

\subsubsection{Screening for Enteropathogenic Escherichia coli}

Morphological examination was applied according to, Cruickshank et al., (1975). Biochemical identification was performed according to, Macfaddin, (1976). Serodiagnosis of E.coli was done according to ,Kok et al.,( 1996)

\subsubsection{Screening for Salmonellae}

Microscopical examination according to ,Cruickshank et al., (1975). Biochemical tests according to ,Macfaddin (1976). Serological identification of Salmonellae according to ,Kauffmann( 1974).

\subsubsection{Screening for Staphylococcus aureus}

Morphological examination according to, Cruickshank et al., (1975). Biochemical tests according to Macfaddin( 1976). Detection of S.aureus enterotoxins by ELISA according to Ewald( 1988).

\subsubsection{Screening for Campylobacter jejuni}

Morphological examination ,Cruickshank et al., (1975). Biochemical identification ,ISO.,( 2004).Serological identification of Campylobacter species by Latex Agglutination Kit according toOyarzabal et al.,(2007).

\section{RESULTS}

The results presented in Table (1) revealed that Salmonella Kentuckey, Salmonella Typhymurium, Salmonella Enteritidis and Salmonella Virchow were detected in $15.7 \%, 12.9 \%, 12.9 \%$ \& $4.3 \%$ of samples taken from farm (A) and $4.3 \%, 4.3 \%$, $5.7 \%$ and $0 \%$ of those samples different taken from farm (B), respectively. Salmonella Kentuckey was isolated from floor, wall, drinker, boots, cloaca, water $(20 \%$ of each), feeder $(40 \%) \&$ litter $(60 \%)$ of farm (A). However, it was isolated from floor, car rubber $(20 \%$ of each) \& cloaca $(40 \%)$ of farm (B). Salmonella Typhymurium was recovered from wall, fan, water, feed; hands ( $20 \%$ of each), boots $\&$ car rubber ( $20 \%$ of each) of farm (A) and feeder, boots \& car rubber (20\% of each) of farm (B). Salmonella Enteritidis was isolated from floor, window, feeder, boots, cloaca, litter, feed $(20 \%$ of each) \& car rubber (40\%) of farm (A) and boots, 
cloaca, litter \& water (20\% of each) of farm (B). While, Salmonella Virchow was isolated from floor, car rubber \& cloaca ( $20 \%$ of each) of farm (A) and it was not detected in any sample related to farm (B).

Incidence of $E$. coli in the examined swabs of the two farms was shown in table (2). Actually, E. coli serotype $\mathrm{O} 1$ was detected in drinker, boots, cloaca, litter ( $20 \%$ of each) \& car rubber $(40 \%)$ of farm (A) and only from car rubbers $(20 \%)$ of farm (B). Moreover, E. coli serotype $\mathrm{O} 2$ was isolated from fans, feeders, feed ( $20 \%$ of each) \& boots $(40 \%)$ of farm (B). However, E. coli serotype O78 was detected in floor, feeder, cloaca, water $(20 \%$ of each) \& feeder \& litter ( $40 \%$ of each) of farm (A) and feeder, cloaca ( $20 \%$ of each) \& litter $(40 \%)$ of farm (B).

Incidence of $S$. aureus and $C$. jejuni in the examined swabs of the two farms $\mathrm{A}$ and $\mathrm{B}$ is indicated in table (3). S. aureus was isolated from wall, fans, cloaca, litter ( $20 \%$ of each), floor, drinker, boots, air ( $40 \%$ of each), car rubbers $(60 \%)$ \& worker hands $(80 \%)$ of farm (A) and was isolated from drinkers \& car rubbers $(20 \%$ of each) of farm (B). While, C. jejuni was recovered from floors, walls, fans, feeders, boots, water $(20 \%$ of each), drinker, cloaca ( $40 \%$ of each) \& litter $(60 \%)$ of farm (A) and only from cloaca and litter $(20 \%$ of each) of farm (B).

Table1. Incidence of Salmonellae in the examined swabs of the farms (A) and (B) $(n=5)$

\begin{tabular}{|c|c|c|c|c|c|c|c|c|}
\hline $\begin{array}{l}\quad \text { Farm } \\
\text { Samples } \\
\text { Swabs } \\
\end{array}$ & \multicolumn{4}{|c|}{$\mathrm{A}$} & \multicolumn{4}{|c|}{$\mathrm{B}$} \\
\hline \multicolumn{9}{|c|}{ Isolates } \\
\hline & $\begin{array}{c}S . \\
\text { Kentucky }\end{array}$ & $\begin{array}{c}. \\
\text { Typhimurium }\end{array}$ & $\begin{array}{c}S . \\
\text { Enteritidis }\end{array}$ & $\begin{array}{c}\text { S. } \\
\text { Virchow }\end{array}$ & $\begin{array}{c}\text { S. } \\
\text { Kentucky }\end{array}$ & $\begin{array}{c}\text { S. } \\
\text { Typhimurium }\end{array}$ & $\begin{array}{c}S . \\
\text { Enteritidis }\end{array}$ & $\begin{array}{c}\text { S. } \\
\text { Virchow }\end{array}$ \\
\hline Floor & $1(20 \%)$ & & $1(20 \%)$ & $1(20 \%)$ & $1(20 \%)$ & 0 & 0 & 0 \\
\hline Wall & $1(20 \%)$ & $1(5 \%)$ & 0 & 0 & 0 & 0 & 0 & 0 \\
\hline Window & 0 & 0 & $1(20 \%)$ & 0 & 0 & 0 & 0 & 0 \\
\hline Fan & 0 & $1(5 \%)$ & 0 & 0 & 0 & 0 & 0 & 0 \\
\hline Drinker & $1(20 \%)$ & 0 & 0 & $1(20 \%)$ & 0 & 0 & 0 & 0 \\
\hline Feeder & $2(40 \%)$ & 0 & $1(20 \%)$ & 0 & 0 & $1(20 \%)$ & 0 & 0 \\
\hline Boots & $1(20 \%)$ & $2(40 \%)$ & $1(20 \%)$ & 0 & 0 & $1(20 \%)$ & $1(20 \%)$ & 0 \\
\hline $\begin{array}{l}\text { Car } \\
\text { Rubber }\end{array}$ & 0 & $2(40 \%)$ & $2(40 \%)$ & 0 & $1(20 \%)$ & $1(20 \%)$ & 0 & 0 \\
\hline Cloaca & $1(20 \%)$ & 0 & $1(20 \%)$ & $1(20 \%)$ & $2(40 \%)$ & 0 & $1(20 \%)$ & 0 \\
\hline Litter & $3(60 \%)$ & 0 & $1(20 \%)$ & 0 & 0 & 0 & $1(20 \%)$ & 0 \\
\hline Water & $1(20 \%)$ & $1(20 \%)$ & 0 & 0 & 0 & 0 & $1(20 \%)$ & 0 \\
\hline Feed & 0 & $1(20 \%)$ & $1(20 \%)$ & 0 & 0 & 0 & 0 & 0 \\
\hline Air & 0 & 0 & 0 & 0 & 0 & 0 & 0 & 0 \\
\hline Hands & 0 & $1(20 \%)$ & 0 & 0 & 0 & 0 & 0 & 0 \\
\hline $\begin{array}{l}\text { Total } \\
\text { (70) }\end{array}$ & $\begin{array}{c}11 \\
(15.7 \%)\end{array}$ & $\begin{array}{c}9 \\
(12.9 \%)\end{array}$ & $\begin{array}{c}9 \\
(12.9 \%)\end{array}$ & $\begin{array}{c}3 \\
(4.3 \%)\end{array}$ & $\begin{array}{c}3 \\
(4.3 \%)\end{array}$ & $\begin{array}{c}3 \\
(4.3 \%)\end{array}$ & $\begin{array}{c}4 \\
(5.7 \%)\end{array}$ & 0 \\
\hline
\end{tabular}

\section{DISCUSSION}

Adequate biosecurity implementations such as using of modern housing, boot dips, and fly screens can successfully reduce the risk of flock infection. However, biosecurity measures, such as cleaning and disinfecting the poultry house between flocks, are also necessary. Reducing flock susceptibility to infection by using appropriately treated water for drinking and discontinuing thinning are important strategies at preventing flock colonization by certain pathogens such as Campylobacters (Newell et al., 2011).
The results revealed that Salmonella Kentuckey, Salmonella Typhymurium, Salmonella Enteritidis and Salmonella Virchow were detected in $15.7 \%$, $12.9 \%, 12.9 \%$ \& $4.3 \%$ of different samples taken from farm (A) and $4.3 \%, 4.3 \%, 5.7 \%$ and $0 \%$ of those samples different taken from farm (B), respectively. Salmonella Kentuckey was isolated from floor, wall, drinker, boots, cloaca, water $(20 \%$ of each), feeder (40\%) \& litter (60\%) of farm (A). However, it was isolated from floor, car rubber (20\% of each) \& cloaca (40\%) of farm (B). Salmonella Typhymurium, was recovered from 
Table2. Incidence of E. coli in the examined swabs of the two farms A and B ( $n=5)$

\begin{tabular}{|c|c|c|c|c|c|c|}
\hline \multirow[t]{2}{*}{$\begin{array}{l}\quad \text { Farm } \\
\text { Samples } \\
\text { Swabs } \\
\end{array}$} & & A & & & B & \\
\hline & \multicolumn{5}{|c|}{ Isolates } & \\
\hline & $\mathrm{O} 1$ & $\mathrm{O} 2$ & $\mathrm{O} 78$ & O1 & $\mathrm{O} 2$ & O78 \\
\hline Floor & 0 & 0 & $1(20 \%)$ & 0 & $1(20 \%)$ & 0 \\
\hline Wall & 0 & 0 & 0 & 0 & 0 & 0 \\
\hline Window & 0 & 0 & 0 & 0 & 0 & 0 \\
\hline Fan & 0 & $1(20 \%)$ & 0 & 0 & 0 & 0 \\
\hline Drinker & $1(20 \%)$ & 0 & 0 & 0 & 0 & 0 \\
\hline Feeder & 0 & $1(20 \%)$ & $2(40 \%)$ & 0 & 0 & $1(20 \%)$ \\
\hline Boots & $1(20 \%)$ & $2(40 \%)$ & $1(20 \%)$ & 0 & 0 & 0 \\
\hline Car Rubber & $2(40 \%)$ & 0 & 0 & $1(20 \%)$ & 0 & 0 \\
\hline Cloaca & $1(20 \%)$ & 0 & $1(20 \%)$ & 0 & 0 & $1(20 \%)$ \\
\hline Litter & $1(20 \%)$ & 0 & $2(40 \%)$ & 0 & 0 & $2(40 \%)$ \\
\hline Water & 0 & 0 & $1(20 \%)$ & 0 & 0 & 0 \\
\hline Feed & 0 & $1(20 \%)$ & 0 & 0 & $1(20 \%)$ & 0 \\
\hline Air & 0 & 0 & 0 & 0 & 0 & 0 \\
\hline Hands & 0 & 0 & 0 & 0 & 0 & 0 \\
\hline Total (70) & $6(8.6 \%)$ & $5(7.1 \%)$ & $8(11.7 \%)$ & $1(1.4 \%)$ & $2(2.8 \%)$ & $4(5.7 \%)$ \\
\hline
\end{tabular}

Table3. Incidence of S. aureus and C. jejuni in the examined swabs of the two farms A and B ( $n=5)$

\begin{tabular}{|c|c|c|c|c|}
\hline \multirow[t]{2}{*}{$\begin{array}{l}\quad \text { Farm } \\
\text { Samples } \\
\text { Swabs } \\
\end{array}$} & & & & \\
\hline & \multicolumn{3}{|c|}{ Isolates } & \\
\hline & S. aureus & C. jejuni & S. aureus & C. jejuni \\
\hline Floor & $2(40 \%)$ & $1(20 \%)$ & 0 & 0 \\
\hline Wall & $1(20 \%)$ & $1(20 \%)$ & 0 & 0 \\
\hline Window & 0 & 0 & 0 & 0 \\
\hline Fan & $1(20 \%)$ & $1(20 \%)$ & 0 & 0 \\
\hline Drinker & $2(40 \%)$ & $2(40 \%)$ & $1(20 \%)$ & 0 \\
\hline Feeder & 0 & $1(20 \%)$ & 0 & 0 \\
\hline Boots & $2(40 \%)$ & $1(20 \%)$ & 0 & 0 \\
\hline Car Rubber & $3(60 \%)$ & 0 & $1(20 \%)$ & 0 \\
\hline Cloaca & $1(20 \%)$ & $2(40 \%)$ & 0 & $1(20 \%)$ \\
\hline Litter & $1(20 \%)$ & $3(60 \%)$ & 0 & $1(20 \%)$ \\
\hline Water & 0 & $1(20 \%)$ & 0 & 0 \\
\hline Feed & 0 & 0 & 0 & 0 \\
\hline Air & $2(40 \%)$ & 0 & 0 & 0 \\
\hline Hands & $4(80 \%)$ & 0 & 3 & 0 \\
\hline Total (70) & $19(27.1 \%)$ & $10(14.3 \%)$ & $5(7.1 \%)$ & $2(2.8 \%)$ \\
\hline
\end{tabular}

walls, fans, water, feeds, hands ( $20 \%$ of each), boots \& car rubbers ( $20 \%$ of each) of farm (A) and (B). Salmonella Enteritidis was isolated from floor, feeder, boots \& car rubber $(20 \%$ of each) of farm windows, feeders, boots, cloaca, litter, feed $(20 \%$ of each) \& car rubbers $(40 \%)$ of farm (A) and boots, cloaca, litter \& water ( $20 \%$ of each) of farm (B). While, Salmonella Virchow was isolated from floor, car rubber \& cloaca ( $20 \%$ of each) of farm
(A) and it was not detected in any sample from farm (B).

Nearly similar findings were recorded by (Messens et al., 2009) who determined the potential sources and vectors for contamination of poultry farms with Salmonellae which are infected livestock and free-living animals, rodents and flies, contaminated surface water and personnel and farm equipment. 
The Salmonella status of the house after cleansing and disinfection can be assessed from gauze-swab samples taken from the wall, feeders, ventilation system and bedding where the house had at least one contaminated sample and is classified as Salmonella-contaminated house (Rose et al., 2000).

Salmonella contamination of poultry in preharvest environments can usually be traced to production issues that include contaminated poultry feed or pathogen introduction to the facilities via a wide range of carriers including house pets, wild animals as well as insects. This is further accentuated by the larger numbers of birds housed in confinement resulting in an increase in more birds being infected simultaneously via aerosols and other routes (Park et al., 2008).

The raw materials of animal and / or vegetable origin could be contaminated with Salmonella. They isolated Salmonella from poultry feeds and feed components at incidence of $10 \%$ and $17 \%$, respectively (Veldman et al., 1995).

Salmonella Enteritidis is frequently surviving outside poultry houses in small pockets of litter and fan dust, which had been left after cleansing and disinfection of the site. Also, Salmonella Enteritidis can survive at least 26 months in artificially contaminated poultry feed (Davies and Wray, 1996). The inability to remove Salmonella Enteritidis from poultry house might be associated in part with the source of field water used for diluting disinfectants. If water from wells, streams and ponds is used to disinfect poultry houses, there was a significant. association between the use of field water and growth of Salmonella Enteritidis (Davison et al., 1996).

All efforts to control Salmonella organisms in poultry farms are complicated by differences in the predominant serotype, strain heterogenecity, prevalence, biosecurity practices, extent of regulatory control and the nature, size and logestic complexity of this industry (Mead et al., 2010).

Incidence of $E$. coli in the examined swabs of the two farms was shown in table (2). Actually, E. coli serotype $\mathrm{O} 1$ was detected in drinker, boots, cloaca, litter ( $20 \%$ of each) \& car rubbers $(40 \%)$ of farm (A) and only from car rubbers (20\%) of farm (B). Moreover, E. coli serotype $\mathrm{O} 2$ was isolated from fans, feeders, feed ( $20 \%$ of each) \& boots $(40 \%)$ of farm (B). However, E. coli serotype O78 was detected in floor, feeder, cloaca, water $(20 \%$ of each) $\&$ feeder $\&$ litter ( $40 \%$ of each) of farm (A) and feeder, cloaca ( $20 \%$ of each) \& litter $(40 \%)$ of farm (B). In general, such strains of $E$. coli were previously isolated from poultry farms by (Barnes et al., 2003).

The common sources of E. coli in Poultry farm may include water, dust, vectors and poorly maintained litter or ventilation systems (Barnes et al., 2003). Also, settled dust may be a source of pathogens that inter the aerosol environment. Therefore, E. coli has been isolated from settled dust collected in residential environments. Litter has ultimately a significant in the generation of dust that can accumulate on walls, the ceiling and other equipment with microorganisms adhering to this dust (Richardson et al., 2003).

The survival of E. coli ranged from 10 to 11 weeks at $38^{\circ} \mathrm{C}$ and 18 weeks at $25^{\circ} \mathrm{C}$, the longevity of E. coli was relatively prolonged in the starter rations than the finisher rations(Ahmad and Sotohy, 1998). Thus, certain $E$. coli strains can become endemic to the farm environment and infect successive flocks (Singer et al., 2000).

Incidence of $S$. aureus and $C$. jejuni in the examined swabs of the two farms was indicated in table (3). Isolatoin of S. aureus from walls, fans, cloaca, and litter was ( $20 \%$ of each), floor, drinker, boots, air $(40 \%$ of each), car rubber $(60 \%) \&$ worker hands $(80 \%)$ of farm (A) and only from drinkers \& car rubbers (20\% of each) from farm (B). While, C. jejuni was recovered from floors, walls, fans, feeders, boots, water ( $20 \%$ of each), drinkers, cloaca $(40 \%$ of each) \& litter $(60 \%)$ of farm (A) and only from cloaca and litter ( $20 \%$ of each) of farm (B).

Horizontal transmission of $C$. jejuni from the environment of the broiler house is the most important route for flock colonization, which often occurs via human traffic and vertical transmission from infected breeder flocks has not been demonstrated and hence horizontal transmission from the environment is more likely (Callicott et al., 2006).

The environment can also be a source of campylobacters colonizing housed broiler flocks (Ring et al., 2005). Once it is established in a poultry house, Campylobacter is known to rapidly spread within the flock infecting the majority of the birds and its prevalence within-flock ranging between 60 and $100 \%$ (Stern et al., 2003).

Campylobacter colonization in poultry usually follows a seasonal pattern, with the peak in warmer months (Bouwknegt et al., 2004). Also, human traffic is a very important vehicle for Campylobacters entering the poultry house from 
the external environment. The presence of rodents in the poultry house has well known the role of these animals as reservoirs of different bacteria, including Campylobacter (Meerburg and KiJlstra, 2007).

The increased risk is associated with the disruption of normal biosecurity practices on the farm and the stress placed on the remaining birds. Following exposure, Campylobacter colonization of these birds develops rapidly, so that high levels of organism may be present in faeces and caecal droppings by the time the flock is cleared, typically 5-8 days following the thinning process (Allen et al., 2008).

Risk factors associated with the prevalence of Campylobacter in chicken farms, such as the higher age of broiler at slaughter, good hygiene practices by farmers, drinking water distribution, the presence of other animals in the vicinity of the farm and heavy rainfall some weeks before the slaughter or seldom or never thinning have been shown to be important factors against Campylobacter infection (Jonsson et al., 2012).

Finally, the decontamination of poultry houses is a delicate operation. It must be obligatory and regulated to avoid any contagion of the breeding flock. It must be also made by a qualified and competent team. The excellent efficacy of the decontamination of poultry houses can be mainly explained by using an HACCP team, supervision of cleanliness, a sanitation including all of buildings, equipment and approaches; moreover a biosecurity program to remove risk factors, was carried out. The sanitary responsible has to convince the breeders of the importance of hygiene measures and disease prevention in the fight against pathologies and the improvement of production performances.

It can be recommended from this study the following points:

- Strict biosecurity measures alone may not be sufficient to control ubiquitous environmental pathogens at the farm level of production.

- Strict pest management with currently available products, such as the compound used in this study, alone may be insufficient for adequate control of potential vectors for the entire production cycle.

- Further analysis, including enumeration, may be required to determine if a combined biosecurity and pest management approach has a significant effect at decreasing pathogen load at the farm level.

\section{REFERENCES}

Ahmad, A.M., 1990. Evaluation of disinfection processes in modern poulrty farms. M.V. Sc. Thesis Hygiene, Fac Vet. Med. Cairo Univesrity.

Ahmad, M. M., Sotohy, S.A., 1998. Survival of Salmonella typhimurium and E.coli in poultry environment under different thermal conditions. Assuit Vet. Med. J. 38, $16-28$.

Allen, V.M., Weaver, H., Ridley, A.M., Harris, J.A., Sharma, M., Emery, J., Sparks, N., Lewis, M., Edge, S., 2008. Sources and spread of thermophilic Campylobacter spp during partial depopulation of broiler chicken flocks. Food protect. 71, 264-270.

Barnes, H.J., Vaillancourt, J., Gross., W.B., 2003. Colibacillosis. Pages 631-656 in Diseases of poultry. 11th ed.

Bouwknegt, M., van de Giessen, A.W., DamDeisz, W.D ,.Havelaar, A.H., Nagelkerke, N.J., Henken, A.M., 2004. Risk factors for the presence of Campylobacter spp. in Dutch broiler flocks. Preventive veterinary medicine 62, 35-49.

Callicott, K.A., Friethriksdottir, V., Reiersen, J., Lowman, R., Bisaillon, J.R ,.Gunnarsson, E., Berndtson, E., Hiett, K.L., Needleman, D.S., Stern, N.J., 2006. Lack of evidence for vertical transmission of Campylobacter spp. in chickens. Appl. and Environ. Microbiol. 72, 5794-5798.

Cruickshank, R., Duguid, J., Marmion, B ,.Swain, R., 1975. Medical Microbiol. 12th, ed., Edinburg, London and New York.

Davies, R.H., Wray, C., 1996. Persistence of Salmonella enteritidis in poultry units and poultry food. Brit. Poult. Scien 37, 589-596.

Davison, S., Benson, C.E ,.Eckroade, R.J., 1996. Evaluation of disinfectants against Salmonella enteritidis. Avian diseases 40, 272-277.

Dvorak, G., 2005. Disinfection 101.The Center for Food Security and Public Health, Lowa State University.

Ewald, S., 1988. Evaluation of enzyme-linked immunosorbent assay (ELISA) for detection of staphylococcal enterotoxin in foods. International journal of food microbiology 6 , 141-153.

Halifa, M., 2008. Good biosecurity practices in non integrated commercial and in scavenging production system in Tanzania. FAO Study report. 
ISO., 2004. International Organization for Standardization. No.1129-1.Microbiology of food and animal feeding stuffs Horizontal methods for the detection and enumeration of Enterobacteriaceae.

Jeffrey, J.S., 1997. Biosecurity of poultry flock. Poultry fact sheet No. 26, Vet. Med., California Univ., 18830 Road 112 Road 112, Tulare, CA 93274.

Jonsson, M.E., Chriel, M., Norstrom, M., Hofshagen, M., 2012. Effect of climate and farm environment on Campylobacter spp. colonisation in Norwegian broiler flocks. Preventive veterinary medicine 107, 95-104.

Kauffmann, G., 1974. Kauffmann white scheme. . J. Acta. Path. Microbiol. Sci. 61, 385.

Kok, T., Worswich, D., Gowans, E., 1996. Some serological techniques for microbial and viral infections. . In Practical Medical Microbiology.

See comment in PubMed Commons below Macfaddin, J.F., 1976. Biochemical tests for identification medical bacteria. Warery press, INC. Baltimore, Md 21202 .USA.

See comment in PubMed Commons below Mead, G., Lammerding, A.M., Cox, N., Doyle, M.P., Humbert, F., Kulikovskiy, A., Panin, A., do Nascimento, V.P., Wierup, M., 2010. Scientific and technical factors affecting the setting of Salmonella criteria for raw poultry: a global perspective. Journal of food protection 73, 1566-1590.

Meerburg, B.G., KiJlstra, A., 2007. Role of rodents in transmission of Salmonella and Campylobacter. J. Sci. Food Agric. 87, 2774-2781.

Messens, W., Herman, L., De Zutter, L., Heyndrickx, M., 200 .9Multiple typing for the epidemiological study of contamination of broilers with thermotolerant Campylobacter. Veterinary microbiology 138, 120-131.

Newell, D.G., Elvers, K.T., Dopfer, D., Hansson, I., Jones, P., James, S., Gittins, J., Stern, N.J., Davies, R., Connerton, I., Pearson, D., Salvat, G., Allen, V.M., 2011. Biosecuritybased interventions and strategies to reduce Campylobacter spp. on poultry farms. Appl. and Environ. Microbiol. 77, 8605-8614.

Oyarzabal, O.A., Backert, S., Nagaraj ,M., Miller, R.S., Hussain, S.K., Oyarzabal, E.A., 2007. Efficacy of supplemented buffered peptone water for the isolation of Campylobacter jejuni and C. coli from broiler retail products. Jour. of Microbiol. Methods 69, 129-136.
Park, S.Y., C.L., W ,.F., K.L., Nisbet, D.J., Birkhold, S.G., Ricke, S.C., 2008. Environmental dissemenetion of foodborne Salmonella in preharvest poultry production : reservoirs, critical factors and research strategies. Crit. Rev. Environ. Sci. Technol.38,73-111.

Richardson, L.J., Hofacre, C.L., Mitchell, B.W., Wilson, J.L., 2003. Effect of electrostatic space charge on reduction of airborne transmission of Salmonella and other bacteria in broiler breeders in production and their progeny. Avian diseases 47, 13521361.

Ring, M., Zychowska, M.A., Stephan, R., 2005. Dynamics of Campylobacter spp. spread investigated in 14 broiler flocks in Switzerland. Avian diseases 49, 390-396.

Rose, N., Beaudeau, F., Drouin, P., Toux, J.Y., Rose, V., Colin, P., 2000 .Risk factors for Salmonella persistence after cleansing and disinfection in French broiler-chicken houses. Preventive veterinary medicine 44, 9-20.

Sharma, B., 2010. Poultry production, management and biosecurity measures. J. Agric. Environ. Rev. 11,120-124

Singer, R.S., Jeffrey, J.S., Carpenter, T.E., Cooke, C.L., Atwill, E.R., Johnson, W.O., Hirsh, D.C., 2000. Persistence of cellulitisassociated Escherichia coli DNA fingerprints in successive broiler chicken flocks. Veter. Microbiol 7: 59-71.

Smith, T., June, W., 1999. Sanitation, cleaning and disinfectants. Mississippi State University Extension Service, Starkville, MS.

Stern, N.J., Hiett, K.L., Alfredsson, G.A., Kristinsson, K.G., Reiersen, J., Hardardottir, H., Briem, H ,.Gunnarsson, E., Georgsson, F., Lowman, R., Berndtson, E., Lammerding, A.M., Paoli, G.M., Musgrove, M.T., 2003. Campylobacter spp. in Icelandic poultry operations and human disease. Epidemiology and infection 130, 23-32.

Veldman, A., Vahl, H.A., Borggreve ,G.J., Fuller, D.C., 1995. A survey of the incidence of Salmonella species and Enterobacteriaceae in poultry feeds and feed components. The Veter. Rec. 136, 169-172.

Williams, J.E., 1975. Avian salmonellosis: detection and characterization of serologic response to major serogroup infections. Am. j. Vet. Res. 36, 591-592. 